\title{
Predictors of Commercialization Success in Product Innovation: A Systematic Research
}

\author{
Norhadilah Abdul Hamid, Azmawani Abd Rahman, Abdul Talib Bon, Yunos Ngadiman, \\ Ahmad Nur Aizat Ahmad
}

\begin{abstract}
This review paper illustrates the routes within the area of innovation commercialization. The routes are extracted from the total of 245 past studies that had been published from year 2007 to year 2015 from numerous established databases. The results from systematic literature review shows that eights main predictors of commercialization has been identified. All eight factors are organizational support, knowledge management, strategic orientation, contextual factors, innovation characteristics, team composition, individual factors and collaboration.
\end{abstract}

\section{Keywords: Commercialization, Success, Product, Innovation,}

\section{INTRODUCTION}

Innovation commercialization is possibly one of the main important challenges being faced by all kinds of innovation companies. Across the century, new technologies have mushroomed rapidly according to an increase in the number of research universities, research institute and competition in the market. The world has seen market demand for new innovations also increasing considerably as vital sources for the generation of national incomes. Innovations play a major role in the economic development of our country because innovations have become one of the vital elements in the business model of a firm. Today, innovation is seen as a requirement for staying competitive in a modest environment, and it is significant for organizations to uphold it in the face of the rapidly changing needs of customers [4].

As [26] pointed out, innovation, can be defined as something that is able to create value, is beyond science or technology. This can be seen, for example, in the competitiveness of mobile phones, such as Samsung, Apple, Sony, Blackberry and others, nowadays. These companies keep revolutionizing their output by introducing innovative technologies or features in order to maintain their sustainability in the market and to survive in the global battle for a share in the market. Another good example is online shopping, which has practically changed the retail market by offering online purchasing. For this reason, firms have to be more innovative to ensure that they are in a comfortable zone in the global market. In short, innovation

Revised Manuscript Received on September 14, 2019.

Norhadilah Abdul Hamid, Faculty of Technology Management and Business, Universiti Tun Hussein Onn Malaysia,86400 Parit Raja Johor, Malaysia. (Email: hadilah@uthm.edu.my)

Azmawani Abd Rahman, Faculty of Economics and Management, Universiti Putra Malaysia, 43400 Serdang Selangor, Malaysia

Abdul Talib Bon, aculty of Technology Management and Business, Universiti Tun Hussein Onn Malaysia,86400 Parit Raja Johor, Malaysia.

Yunos Ngadiman, aculty of Technology Management and Business, Universiti Tun Hussein Onn Malaysia,86400 Parit Raja Johor, Malaysia.

Ahmad Nur Aizat Ahmad, aculty of Technology Management and Business, Universiti Tun Hussein Onn Malaysia,86400 Parit Raja Johor, Malaysia. is necessary in order for companies to remain relevant in the market.

The failure of new innovation in commercialization stage is rising at an alarming rate even though large amount of previous studies mentioned the success story of innovation. In fact, greater part of previous findings affirm that most of the innovations are affluent at the stage of research and development (R\&D) and in the initial phase of product development, but it will not definitely lead to triumph when it enter the market during commercialization phase [35]. This was why [23] stated that the success of commercialization is one of the crucial agendas that need more research and further investigation. Thus, many researchers have attempted to identify the barriers and challenges in the commercialization of new technologies and to investigate the factors that lead to the successful commercialization of new innovations. As the result of a systematic literature review, some of the positive significant factors were identified, and all these factors are discussed in the subsection as below.

\section{MATERIALS AND METHODS\& METHODOLOGY}

This section discusses previous studies by reviewing approximately 245 relevant articles. Only studies that actually measured commercialization were included in this systematic literature review. The purpose of a systematic literature review (SLR) is to outline areas of uncertainty in a research in order to identify gaps in the research area and to recommend opportunities for future research [67]. In addition, a SLR involves explicit and rigorous methods to critically assess and synthesize relevant research studies [9]. The purpose of the systematic literature review was to discover the factors and variables that impel commercialization success of innovation.

The following procedure has been conducted to discover and retrieve primary empirical studies pertinent to the research question. It follows the methodological instructions has been designed. The procedure starts with the determination of the dependent variable which is commercialization performance. With the intention of search for related searching for related papers, a few databases were used such as EBSCOhost and Web of Science. The majority of the literature belongs to cited and high ranked journals. The articles being reviewed were browsed from different disciplines. For the next step, selection of the studies, a search was conducted within the 7 


\section{PREDICTORS OF COMMERCIALIZATION SUCCESS IN PRODUCT INNOVATION: A SYSTEMATIC RESEARCH}

years starting from 2007 until 2015. The screening was made based on the keyword (i.e commercialization, innovation, innova, market, success).

Referring to the discussion above, commercialization is one of the components in innovation process. Therefore, researcher seems have to limit only on articles that indicate commercialization performance as innovation success. The findings of analysis from the selected articles, innovation success has been measured by number of publication, product speed to market, product novelty, and patent data. However, referring to the commercialization definition, it signifies the conversion of $R \& D$ innovation or project into marketable or profitable products. As a result, all papers that used these types of indicators have been excluded from the list. For example like patenting measure, according to [12], patent protection negatively influences the company's profit growth directly but partially mediated by commercialization. This result showed that patenting protection is only helps the commercialization process [12]. This result concluded that the patenting is not the best indicators for innovation success; it is just as a protection for commercialization process.

Therefore, for the purpose of this study, the researcher has chosen to focus on articles that indicate commercialization performance as an innovation success. From the literature review, it was apparent that many studies have been carried out by scholars to identify the factors of innovation commercialization that affect commercialization performance. Based on a frequency analysis, 245 articles related to commercialization performance from the year 2007 to 2015 were shortlisted from the database. An analysis of the number of articles based on the year is shown below in Table 1 .

Table 1: Number of Reviewed Studies with respect to Publication Year

\begin{tabular}{|l|l|l|l|}
\hline Year & $\begin{array}{l}\text { Number } \\
\text { of } \\
\text { Articles }\end{array}$ & Years & $\begin{array}{l}\text { Number of } \\
\text { Articles }\end{array}$ \\
\hline 2007 & 13 & 2012 & 30 \\
\hline 2008 & 26 & 2013 & 30 \\
\hline 2009 & 16 & 2014 & 33 \\
\hline 2010 & 27 & 2015 & 30 \\
\hline 2011 & 40 & Total & 123 \\
\hline Total & 122 & $\begin{array}{l}\text { Total } \mathbf{( 2 0 0 7}- \\
\text { 2015) }\end{array}$ & $\mathbf{2 4 5}$ \\
\hline
\end{tabular}

The reviewed articles were browsed from different disciplines. 245 number articles were selected as sample studies; consist of 80 journals and 10 conference proceedings. The vast number of the literature classified as cited and highly ranked journals. Most of selected paper came from the Technovation, Research Policy, Industrial Marketing Management, Journal of Product Innovation Management, and Journal of Technology Transfer. Table 2 shows the total of articles comes from all 80 journals while Table 3 shows 19 articles on ISI proceedings from 10 different conferences.

Table 2: Number of Reviewed Journals with respect to Publication Source Number of reviewed journals with respect to publication source

\begin{tabular}{|c|c|c|c|}
\hline Name of journal & $\begin{array}{l}\text { No of } \\
\text { articles }\end{array}$ & Name of journal & $\begin{array}{l}\text { No of } \\
\text { articles }\end{array}$ \\
\hline A Journal of the Decision Science Institutes & 1 & $\begin{array}{l}\text { Journal of Business } \quad \text { Marketing } \\
\text { Management }\end{array}$ & 1 \\
\hline Academy of Management Journal & 1 & Journal of Business Research & 6 \\
\hline Academy of Entrepreneurship Journal & 1 & $\begin{array}{l}\text { Journal of Business and Industrial } \\
\text { Marketing }\end{array}$ & 1 \\
\hline Annals of Regional Science & 4 & Journal of Business and Venturing & 3 \\
\hline Asia Pacific Journal of Management & 1 & Journal of Commercial Biotechnology & 2 \\
\hline Asian Journal of Technology Innovation & 1 & Journal of Innovation Management & 1 \\
\hline Asian Business \& Management & 1 & $\begin{array}{l}\text { Journal of Innovation } \quad \text { and } \\
\text { Entrepreneurship }\end{array}$ & 1 \\
\hline Asian Social Science & 1 & Journal of Operations Management & 1 \\
\hline African Journal of Business Management & 2 & $\begin{array}{l}\text { Journal of Product and Brand } \\
\text { Management }\end{array}$ & 2 \\
\hline Baltic Journal of Management & 1 & Journal of Management Studies & 4 \\
\hline British Journal of Management & 1 & Journal of Management \& Organization & 1 \\
\hline
\end{tabular}

Table 2 (Cont'd)

Creativity and Innovation Management

Creativity Research Journal

European Journal of Innovation Management

1

1

European Journal of Marketing

Expert Systems with Application

IEEE Computer Strategy
Journal of Communication 1

Journal of Engineering and Technology 3

Management

Journal of Small and Business 1

Management

Journal of Technology Transfer $\quad 12$

Long Range Planning

Management Research Review 
IEEE Transaction on Engineering Management 4 Industrial Management and Data System 2 Industrial Marketing Management $\quad 14$ Innovation-Management Policy \& Practice 3 International Journal of Organizational Innovation $\quad 2$ International Business Journal 1 International Business Review 2 International Journal of Business and Management 1 International Journal of Business Innovation and 1 Research

International Journal of Innovation Management $\quad 1$

International Journal of Electronic Business 1

Management

International Journal of Engineering Innovation \& 2 Management

International Journal of Research and Marketing $\quad 1$

International Journal of Technology Management 1

International Small Business Journal 2

Industrial and Corporate Change 3

Journal of Marketing

Journal of Economics \& Management Strategy

Journal of International Marketing

Journal of International Management

1

Journal of Product Innovation Management

17

Journal of Business Ethics

1

Journal of Purchasing and Supply Chain

1

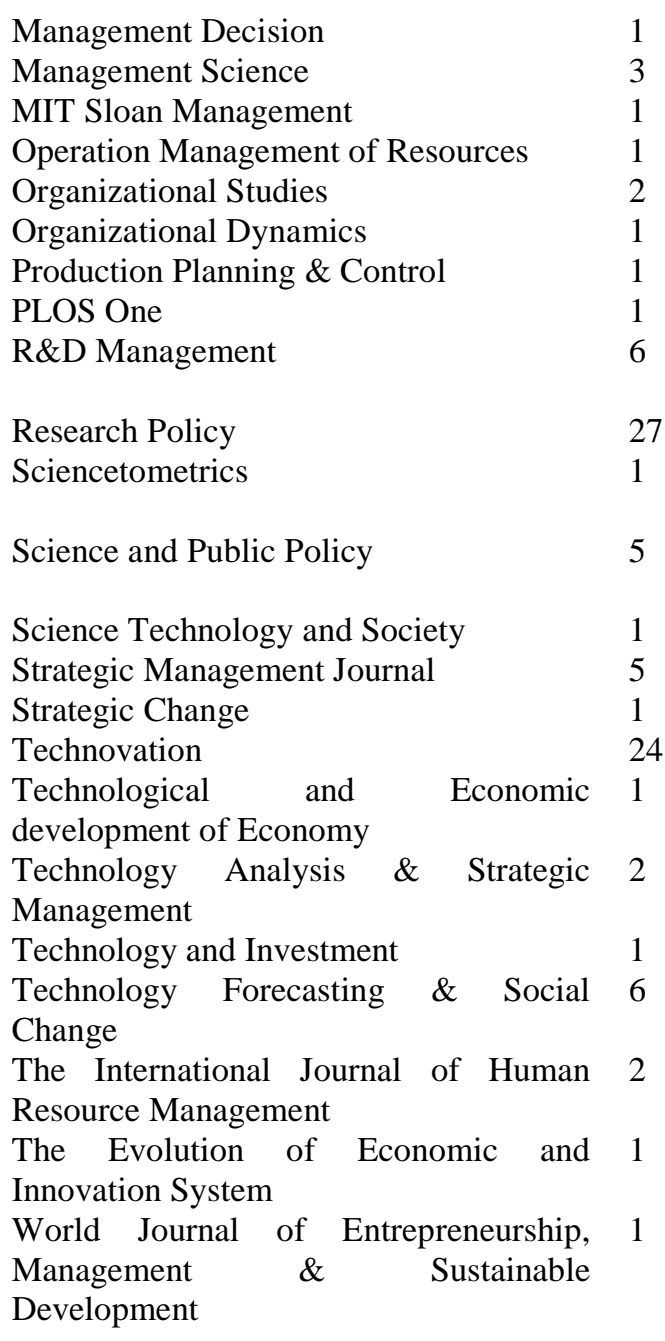

\section{RESULTS}

\subsection{Factors that affect the success of innovation commercialization}

Previous literature review revealed eight factors that affect innovation commercialization performance. The first factor was organizational support. It believes that; firm's performance enhancement might need effective and appropriate assistance to speed up their innovation to enter the market. Organizational support or perceived organizational supports indicate on how an organization concerns of its employee with expectation that at the end their organizational goal will fulfilled [20]. All organizational support mentioned above include information technology tools and technology ([18]; [27]; [70]), systematic patenting system ([22]; [30]), top management support ([36]; [61]), manufacturing [40], organizational capabilities such as marketing ([40] ; [83]), learning or training [40], research and development [40], rewards [45], organizational innovativeness ([32]; [36]; [41]; [79]; [85]), and lastly new product development capabilities [49]. Furthermore, from the results, it has been proven that organizational resources have a positive effect on innovation commercialization performances. These are the studies that shows the positive effect of financial resources ([21]; [31]; [80]), technological resources ([34];[58]), and lastly human resources ([51]; [60]; [75]; [77]; [81]) towards commercialization performance.

Second factor that identified beside the organizational support was knowledge management. This component is essential in accelerating commercialization [37]. The knowledge management can be defined as a process of discovering, capturing and leveraging on the collective knowledge in an organization to facilitate its competitiveness/competitive edge [80]. A few findings have recommended that knowledge management could support firms to increase their commercialization performance ([14]; [17]; [21]; [31]; [33]; [42]; [50]; [61]; [63]; [72]; [78]; [82]; [87]; [88]). Knowledge management here was referring to knowledge exploration, knowledge integration, knowledge exploitation, knowledge on market, and lastly explicit and tacit knowledge. Undeniable, a firm who intends to speed up their commercialization of innovative products need all these kind of knowledge.

Based on the SLR analysis, it has been identified that firm's orientation plays an important role on the success of innovation commercialization and strategic orientation is the most widely type of firms' orientation studied by researchers. Strategic orientation was categorized as market

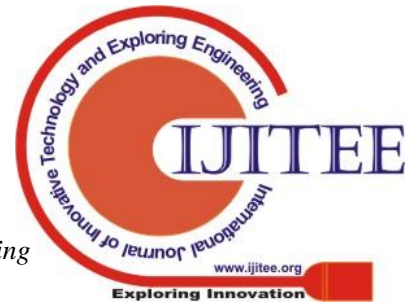




\section{PREDICTORS OF COMMERCIALIZATION SUCCESS IN PRODUCT INNOVATION: A SYSTEMATIC RESEARCH}

orientation [66], entrepreneurial orientation ([10]; [25]; [52]; [57]; [64]), network orientation [64], technological orientation [64], industrial orientation ([6]; [33]), and research orientation [6].

The systematic literature review results also indicate that contextual factor is one of the variables tested for successful commercialization. Contextual factor are external influences that affect the innovation commercialization, such as, political and legal, economic, social and cultural factors. This shows that external factor plays an important role in ensuring the marketability of an innovation. There are few studies apply this variable as moderator [58]; while there were another studies employed it as independent variable meaning that, it has a direct relationship with commercialization performance ([16]; [53]; [55]; [63]; [90]). According to [37] and [45], the external environment example, capital situation and labor, shaped from government may also influence the innovation market ([6]; [39]; [56]; [76]).

The next factor discussed in previous literature was innovation characteristics. Innovation characteristics according to [19], refers to the innovation scope, tacitness, newness and relatedness. Meanwhile, according to [69], the characteristics of innovation are patent, commercial uncertainty, technology dynamism, and complementary assets. In addition there are several authors that also discussed the details on the other elements of innovation characteristics (e.g., [2]; [3]; [7]; [15]; [18]; [19]; [28]; [32]; [34]; [38]; [41]; [46]; [47]; [48]; [62]; [66]; [68]; [69]; [70]; [72]; [71]; [73]; [74]; [76]; [81]; [82]; [87]; [90]; [91]) which has a significant effect on innovation commercialization performance ([8]; [13]; [24]; [29]; [32]; [47]; [77]). A team is defined as the collection of individuals who share responsibilities for an outcome [8]. Teamwork factor is one of the factors widely discussed in innovation commercialization context.

The eighth factors on top of team composition, is individual factor such as individual experience [45], encouragement and emotional ([2]; [11]; [13];[32]; [38]; [55];[61]; N. [88]) which also contribute to the innovation commercialization performance.

Apart from these factors, the least discussed notion is the effect of collaboration towards innovation commercialization performance. According to [1], previous studies seldom referred explicitly to commercialization networks. The majority of the researches on innovation discussed innovation and the research and development (R\&D) network. After analysing all the 245 journals, only 64 articles $(26 \%)$ or less than $50 \%$ discussed collaboration in the context of commercialization. A summary of the articles is given in Figure 1:
Team composition has been identified as the sixth factor

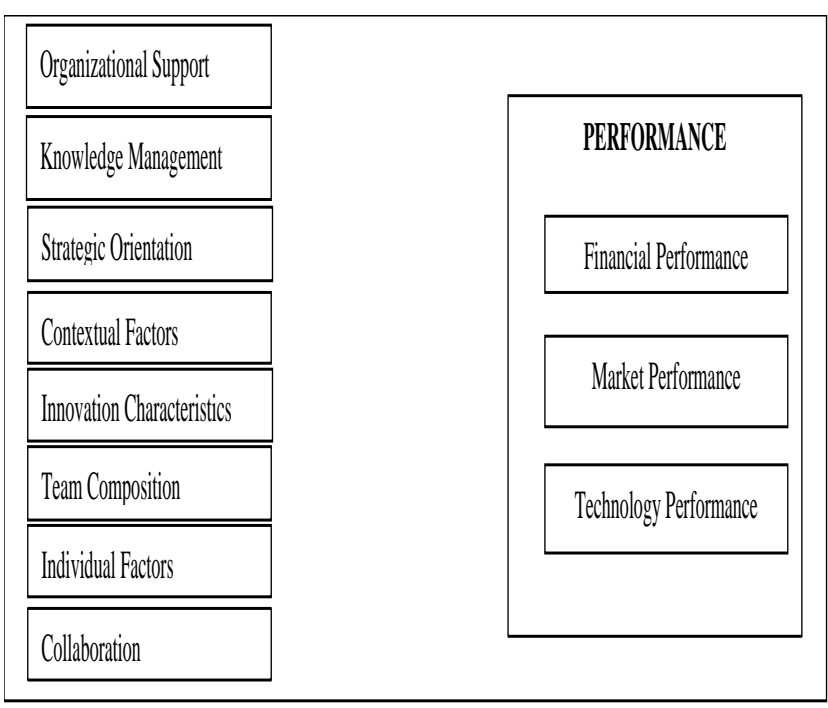

Figure. 1: Summary of SLR Findings

\section{CONCLUSION}

This paper presents a result of a systematic literature review from previous studies. Based on the results, there are eight predictors identified that effect commercialization performance; organizational support, knowledge management, strategic orientation, contextual factors, innovation characteristics, team composition, individual factors and collaboration. However, based on the analysis of reviewed paper, least scholars discussed on the collaboration factors. Therefore, it was suggested that future research should focused on the effect of collaboration towards commercialization performance.

\section{REFERENCES}

1. Aarikka-Stenroos, L., \& Sandberg, B. (2012). From newproduct development to commercialization through networks. Journal of Business Research, 65(2), 198-206.

2. Akgün, A. E., Keskin, H., \& Byrne, J. (2009). Organizational emotional capability, product and process innovation, and firm performance: An empirical analysis. Journal of Engineering and Technology Management, 26(3), 103-130.

3. Akroush, M. N. (2012). Organizational capabilities and new product performance: The role of new product competitive advantage. Competitiveness Review: An International Business Journal Incorporating Journal of Global Competitiveness, 22(4), 343-365.

4. Altuntas, S., \& Dereli, T. (2012). An evaluation index system for prediction of technology commercialization of investment projects, 23, 327-343.

5. Arvanitis, S., Kubli, U., \& Woerter, M. (2008). University-industry knowledge and technology transfer in Switzerland: What university scientists think about cooperation with private enterprises. Research Policy, 37(10), 1865-1883.

6. Behboudi, M., Jalili, N., \& Mousakhani, M. (2011). Examine the Commercialization Research Outcomes in Iran A Structural Equation Model. International Journal of Business and Management, 6(7), 261-276.

7. Bercovitz, J., \& Feldman, M. (2008). Academic Entrepreneurs: Organizational Change at the Individual Level. Organization Science, 19(1), 69-89. 
8. Bercovitz, J., \& Feldman, M. (2011). The mechanisms of collaboration in inventive teams: Composition, social

9. Bongartz, T., Sutton, A. J., Sweeting, M. J., Buchan, I., \& Matteson, E. L. (2006). Anti-TNF Antibody Therapy in Rheumatoid Arthritis and the Risk. The Journal of the American Medical Association, 295(19).

10. Boso, N., Story, V. M., \& Cadogan, J. W. (2013). Journal of Business Venturing Entrepreneurial orientation market orientation, network ties, and performance: Study of entrepreneurial fi rms in a developing economy, 28, 708-727.

11. Buenstorf, G. (2009). Is commercialization good or bad for science? Individual-level evidence from the Max Planck Society. Research Policy, 38(2), 281-292.

12. Cao, Y., \& Zhao, L. (2013). Analysis of patent management effects on technological innovation performance. Baltic Journal of Management, 8(3), 286305.

13. Černe, M., Jaklič, M., \& Škerlavaj, M. (2013). Decoupling management and technological innovations Resolving the individualism-collectivism controversy. Journal of International Management, 19(2), 103-117.

14. Chen, Y.-C., Li, P.-C., \& Evans, K. R. (2012). Effects of interaction and entrepreneurial orientation on organizational performance: Insights into market driven and market driving. Industrial Marketing Management, 41(6), 1019-1034. positive effects of relationship learning and absorptive capacity on innovation performance and competitive advantage in industrial markets. Industrial Marketing Management, 38(2), 152-158.

16. Cheng, C. C., \& Krumwiede, D. (2010). The effects of market orientation and service innovation on service industry performance: An empirical study. Operations

17. Chiang, Y.-H., \& Shih, H.-A. (2011). Knowledgeoriented human resource configurations, the new product development learning process, and perceived new product performance. The International Journal of Human Resource Management, 22(15), 3202-3221.

18. Cho, J., \& Lee, J. (2013). Expert Systems with Applications Development of a new technology product evaluation model for assessing commercialization opportunities using Delphi method and fuzzy AHP approach, 40, 5314-5330.

19. Clarysse, B., Wright, M., \& Van de Velde, E. (2011) Entrepreneurial Origin, Technological Knowledge, and the Growth of Spin-Off Companies. Journal of Management Studies, 48(6), 1420-1442.

20. Colakoglu, U., Culha, O., \& Atay, H. (2010). The Effects of Perceived Organizational Support on Employees' Affective Outcomes: Evidence from the Hotel Industry, $16(2), 125-150$

21. Cousins, P. D., \& Lawson, B. (2007). The Effect of Socialization Mechanisms and Performance Measurement on Supplier Integration in New Product Development. British Journal of Management, 18(3), 311-326.

22. Datta, A. (2011). Corporate Reputation and the Commercialization of Innovation: Does Reputation Match Reality, and Does Innovation Matter? Technology and Investment, 2, 256-272.

23. Datta, A., Reed, R., \& Jessup, L. (2013), Commercialization of innovations: an overarching framework and research agenda. American Journal of Business, 28(2), 147-191.

24. Dayan, M., \& Basarir, A. (2010). Antecedents and consequences of team reflexivity in new product networks, and geography. Research Policy, 40(1), 81-93.

15. Chen, Y.-S., Lin, M.-J. J., \& Chang, C.-H. (2009). The Management Research, 3(3-4), 161-171. https://doi.org/10.4236/ti.2011.24027

development projects. Journal of Business \& Industrial Marketing, 25(1), 18-29.

25. De Clercq, D., Dimov, D., \& Thongpapanl, N. (Tek) (2010). The moderating impact of internal social exchange processes on the entrepreneurial orientationperformance relationship. Journal of Business Venturing, 25(1), 87-103.

26. Drucker, P. F. (1974). Management: Tasks, Responsibility, Practices. New York: Harper \& Row.

27. Durmuşoğlu, S. S., \& Barczak, G. (2011). The use of information technology tools in new product development phases: Analysis of effects on new product innovativeness, quality, and market performance. Industrial Marketing Management, 40(2), 321-330.

28. Eggert, A., Thiesbrummel, C., \& Deutscher, C. (2014). Differential effects of product and service innovations on the financial performance of industrial firms. Journal of Business Marketing Management, 7(3), 380-405.

29. Fernández, P., Luisa Del Río, M., Varela, J., \& Bande, B. (2010). Relationships among functional units and new product performance: The moderating effect of technological turbulence. Technovation, 30(5-6), 310321.

30. Fiedler, M., \& Welpe, I. M. (2010). Antecedents of cooperative commercialisation strategies of nanotechnology firms. Research Policy, 39(3), 400-410.

31. Frishammar, J., Lichtenthaler, U., \& Rundquist, J. (2012). Identifying Technology Commercialization Opportunities: The Importance of Integrating Product Development Knowledge. Journal of Product Innovation Management, 29(4), 573-589.

32. Galbraith, C. S., Denoble, A. F., \& Ehrlich, S. B. (2012). Predicting the Commercialization Progress of early-stage technologies: An ex-ante analysis. IEEE Transactions on Engineering Management, 59(2), 213-225.

33. García, N., Sanzo, M. J., \& Trespalacios, J. a. (2008). New product internal performance and market performance: Evidence from Spanish firms regarding the role of trust, interfunctional integration, and innovation type. Technovation, 28(11), 713-725.

34. Gilbert, B. A., McDougall, P. P., \& Audretsch, D. B. (2008). Clusters, knowledge spillovers and new venture performance: An empirical examination. Journal of Business Venturing, 23(4), 405-422.

35. Gruber, M., MacMillan, I. C., \& Thompson, J. D. (2008). Look Before You Leap: Market Opportunity Identification in Emerging Technology Firms. Management Science, 54(9), 1652-1665.

36. Harborne, P., \& Hendry, C. (2012). Commercialising new energy technologies: failure of the Japanese machine? Technology Analysis \& Strategic Management 24(5), 497-510.

37. Harmancioglu, N., Grinstein, A., \& Goldman, A. (2010). Innovation and performance outcomes of market information collection efforts: The role of top management team involvement. International Journal of Research in Marketing, 27(1), 33-43.

38. Heng, L. H., Rasli, A. M., \& Senin, A. A. (2012) Knowledge Determinant in University Commercialization: A Case Study of Malaysia Public University. Procedia - Social and Behavioral Sciences, 40, 251-257.

39. Jang, Y. (2014). Dynamica of Fast Market Entrance for Young Entrepreneurial Firms Providing Products in Markets: Innovaion, Organization and Entrepreneurs. Academy of Entrepreneurship Journal, 20(1), 75-99. 


\section{PREDICTORS OF COMMERCIALIZATION SUCCESS IN PRODUCT INNOVATION: A SYSTEMATIC RESEARCH}

40. Kang, J., Gwon, S., Kim, S., \& Cho, K. (2013). Determinants of successful technology commercialization: implication for Korean Governmentsponsored SMEs. Asian Journal of Technology Innovation, 21(1), 72-85.

41. Kim, S. K., Lee, B. G., Park, B. S., \& Oh, K. S. (2011). The effect of R\&D, technology commercialization capabilities and innovation performance. Technological and Economic Development of Economy, 17(4), 563578.

42. Kock, A., Gemünden, H. G., Salomo, S., \& Schultz, C. (2011). The Mixed Blessings of Technological Innovativeness for the Commercial Success of New Products. Journal of Product Innovation Management, 28(1), 28-43.

43. Kostopoulos, K., Papalexandris, A., Papachroni, M., \& Ioannou, G. (2011). Absorptive capacity, innovation, and financial performance. Journal of Business Research, 64(12), 1335-1343

44. Kotha, R. R. (n.d.). Bridging the mutual knowledge gap: Coordination and the commercialization.

45. Kotha, R. R., Srikanth, K., \& George, G. (2010). Bridging the mutual knowledge gap: Coordination and the commercialization of radical science. Academic Management Process, 1(1), 1-6.

46. Lam, A. (2011). What motivates academic scientists to engage in research commercialization: "Gold", "ribbon" or "puzzle"? Research Policy, 40(10), 1354-1368.

47. Lee, K. B., \& Wong, V. (2012). Organizational coordination, development proficiency, and on-time completion of development and international rollout: A contingency analysis of external environments. Journal of Business Research, 65(3), 389-401.

48. Lee, L. T.-S. (2008). The effects of team reflexivity and innovativeness on new product development performance. Industrial Management \& Data Systems, 108(4), https://doi.org/10.1108/02635570810868380

$548-569$.

49. Lejpras, A., \& Stephan, A. (2009). Locational conditions, cooperation, and innovativeness: evidence from research and company spin-offs. The Annals of Regional Science, 46(3), 543-575.

50. Lew, Y. K., \& Sinkovics, R. R. (2013). Crossing Borders and Industry Sectors: Behavioral Governance in Strategic Alliances and Product Innovation for Competitive Advantage. Long Range Planning, 46(1-2), 13-38.

51. Lew, Y. K., Sinkovics, R. R., \& Kuivalainen, O. (2013). Upstream internationalization process: Roles of social capital in creating exploratory capability and market performance. International Business Review, 22(6), 1101-1120.

52. Li, Y.-H., \& Huang, J.-W. (2012). Ambidexterity's mediating impact on product development proficiency and new product performance. Industrial Marketing Management, 41(7), 1125-1132.

53. Li, Y., Guo, H., Liu, Y., \& Li, M. (2008). Incentive Mechanisms, Entrepreneurial Orientation, and Technology Commercialization: Evidence from China's Transitional Economy, (86), 63-78.

54. Liao, T.-S., Rice, J., \& Martin, N. (2011). The role of the market in transforming training and knowledge to superior performance: evidence from the Australian manufacturing sector. The International Journal of Human Resource Management, 22(2), 376-394.

55. Libaers, D. P. (2012). Time Allocation Decisions of Academic Scientists and Their Impact on Technology Commercialization. IEEE Transactions on Engineering Management, 59(4), 705-716.

56. Lichtenthaler, U., \& Ernst, H. (2009). The Role of Champions in the External Commercialization of

Knowledge. Journal of Product Innovation Management, 26(4), 371-387.

57. Link, A. N., \& Scott, J. T. (2010). Government as entrepreneur: Evaluating the commercialization success of SBIR projects. Research Policy, 39(5), 589-601.

58. Liu, H., Hou, J., Yang, P., \& Ding, X. (2011). Entrepreneurial orientation, organizational capability and competitive advantage in emerging economies: Evidence from China, 5(May), 3891-3901.

59. Luca, L. M. De, \& Atuahene-gima, K. (2007). Market Knowledge Dimensions and Cross-Functional Collaboration: Examining the Different Routes to, 71(January), 95-112.

60. Ma, C., Yang, Z., Yao, Z., Fisher, G., \& Fang, E. (Er). (2012). The effect of strategic alliance resource accumulation and process characteristics on new product success: Exploration of international high-tech strategic alliances in China. Industrial Marketing Management, 41(3), 469-480.

61. Markham, S. K., Ward, S. J., Aiman-Smith, L., \& Kingon, A. I. (2010). The Valley of Death as Context for Role Theory in Product Innovation. Journal of Product Innovation Management, 27(3), 402-417.

62. Martín-rojas, R., García-morales, V. J., \& Bolívar-ramos, M. T. (2013). Technovation In fl uence of technological support, skills and competencies, and learning on corporate entrepreneurship in European technology fi rms.

63. McNally, R. C., Cavusgil, E., \& Calantone, R. J. (2010). Product Innovativeness Dimensions and Their Relationships with Product Advantage, Product Financial Performance, and Project Protocol. Journal of Product Innovation Management, 27(7), 991-1006.

64. Mishra, S. S. (2013). Moderating roles of organizational inertia and project duration in the NPD process: an empirical investigation. Journal of Product \& Brand Management, 22(1), 52-64.

65. Mu, J., \& Di Benedetto, C. A. (2011). Strategic orientations and new product commercialization: mediator, moderator, and interplay. $R \& D$ Management, 41(4), 337-359.

66. Narver, J. C., Slater, S. F., \& Maclachlan, D. L. (2004). Responsive and Proactive Market Orientation and NewProduct Success, (1990), 334-347.

67. O'Cass, A., \& Sok, P. (2014). The role of intellectual resources, product innovation capability, reputational resources and marketing capability combinations in firm growth. International Small Business Journal, 32(8), 996-1018.

68. Petticrew, M., \& Roberts, H. (2006). Systematic Reviews in the Social Sciences: A Practical Guide. USA Blackwell Publishing.

69. Plewa, C., Korff, N., Johnson, C., Macpherson, G. Baaken, T., \& Rampersad, G. C. (2013). The evolution of university-industry linkages-A framework. Journal of Engineering and Technology Management, 30(1), 21-44.

70. Pries, F., \& Guild, P. (2007). Commercial exploitation of new technologies arising from and markets for technology, (1), 319-328.

71. Protogerou, a., Caloghirou, Y., \& Lioukas, S. (2011) Dynamic capabilities and their indirect impact on firm performance. Industrial and Corporate Change, 21(3), 615-647.

72. Rhee, J., Park, T., \& Lee, D. H. (2010). Drivers of innovativeness and performance for innovative SMEs in South Korea: Mediation of learning orientation. Technovation, 30(1), 65-75. 
73. Rundquist, J. (2012). the Ability To Integrate Different Types of Knowledge and Its Effect on Innovation Performance. International Journal of Innovation Management, 16(2), 1250014

74. Saji, K. B. (2013). Investigating the role of firm resources and environmental variables in new product commercialization. Journal of Product \& Brand Management, 22(1), 18-29.

75. Sanchez, A. R., \& Policy, T. (2010). Exclusivity in Licensing Alliances: Using Hostage to Support Technology Commercialization, , 186(July), 159-186.

76. Sohn, S. Y., \& Jung, C. S. (2010). Effect of Creativity on Innovation: Do Creativity Initiatives Have Significant Impact on Innovative Performance in Korean Firms? Creativity Research Journal, 22(3), 320-328.

77. Song, M., Kawakami, T., \& Stringfellow, A. (2010). A Cross-National Comparative Study of Senior Management Policy, Marketing-Manufacturing Involvement, and Innovation Performance. Journal of Product Innovation Management, 27(2), 179-200.

78. Tellis, G. J., Prabhu, J. C., \& Chandy, R. K. (2009). Radical Innovation Across Nations: The Preeminence of Corporate, 73(January), 3-23.

79. Therrien, P., Doloreux, D., \& Chamberlin, T. (2011) Technovation Innovation novelty and ( commercial) performance in the service sector: A Canadian firm-level analysis, 31, 655-665.

80. Tsai, K., \& Yang, S. (2013). Industrial Marketing Management Firm innovativeness and business performance: The joint moderating effects of market turbulence and competition.

81. von Krogh, G. (1998). Care in Knowledge Creation, 40(3), 133-153.

82. Wagner, S. M. (2010). Supplier traits for better customer firm innovation performance. Industrial Marketing Management, 39(7), 1139-1149.

83. Wang, K.-J., \& Lestari, Y. D. (2013). Firm competencies on market entry success: Evidence from a high-tech industry in an emerging market. Journal of Business Research, 66(12), 2444-2450.

84. Wang, Z., \& Wang, N. (2012). Knowledge sharing, innovation and firm performance. Expert Systems with Applications, 39(10), 8899-8908.

85. Wilden, R., Gudergan, S. P., Nielsen, B. B., \& Lings, I (2013). Dynamic Capabilities and Performance: Strategy, Structure and Environment. Long Range Planning, 46(12), 72-96

86. Wu, S., \& Lin, C.-L. (2011). The influence of Innovation Strategy and Organizational Innovation on Innovation Quality and Performance. Interational Journal of

87. Wu, W. (2009). Managing and incentivizing research commercialization in Chinese Universities. The Journal of Technology Transfer, 35(2), 203-224.

88. Yaacob, N., Rasli, A., Senin, A., \& Norezam, S. (1998) Commercialisation Activities of Research Results among Academic Researchers in Malaysia. Kmice.cms.net.my, 205-211. Retrieved from

89. Yalcinkaya, G., Calantone, R. J., \& Griffith, D. a. (2007) An Examination of Exploration and Exploitation Capabilities: Implications for Product Innovation and Market Performance. Journal of International Marketing, 15(4), 63-93.

90. Yao, Z., Yang, Z., Fisher, G. J., Ma, C., \& (Er) Fang, E. (2013). Knowledge complementarity, knowledge absorption effectiveness, and new product performance: The exploration of international joint ventures in China. International Business Review, 22(1), 216-227.

91. Yuan, L., Zhongfeng, S., \& Yi, L. (2010). Can strategic flexibility help firms profit from product innovation? Technovation, 30(5-6), 300-309. Organizational Innovation, 3(4), 45-82.

92. Zhou, K. Z., Brown, J. R., \& Dev, C. S. (2009). Market orientation, competitive advantage, and performance: A demand-based perspective. Journal of Business Research, 62(11), 1063-1070.

\section{AUTHOR PROFILES}

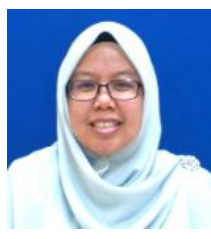

Norhadilah Abdul Hamid is working as lecturer at Faculty of Technology Management and Business, Universit Tun Hussein Onn Malaysia. Her major research interest is Technology Commercialisation.

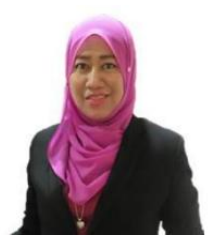

Associate Professor Dr. Azmawani Abd Rahman holds a Bachelor of Science in Finance from the University of South Alabama (United States), a Master of Science in Management from the Universiti

Putra Malaysia, and a Ph.D. in Operations and Technology Management from Aston University (United Kingdom). For her Ph.D. work, Azmawani was awarded a lifetime membership in Beta Gamma Sigma, the highest recognition for business students worldwide. She is currently an Associate Professor at Department of Management and Marketing and Deputy Dean (Research \& Industry and Community Relations) at the Faculty of Economics and Management at Universiti Putra Malaysia. She is also an associate researcher at Halal Products Research Institute.

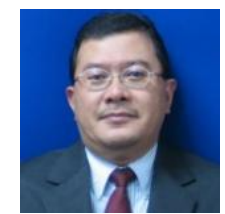

Abdul Hadi Nawawi, PhD is a Professor of Technology Management at Faculty of Technology Management and Business, Universiti Tun Hussein Onn Malaysia. Currently, he is the director of teaching factory at Universiti Tun Hussein Onn Malaysia. His main area of interests are Operation Research and Management Science.

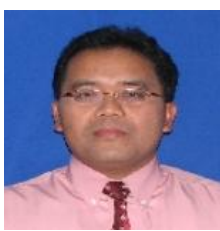

Yunos Ngadiman is working as lecturer at Faculty of Technology Management and Business, Universiti Tun Hussein Onn Malaysia. Her major research interest is Technology Commercialisation. His main area of interest is Industrial and Manufacturing Engineering.

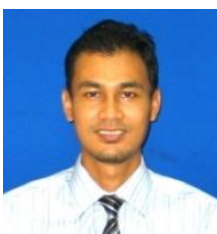

Ahmad Nur Aizat Ahmad currently works at the Department of Production and Operations, Universiti Tun Hussein Onn Malaysia. His research interest includes Manufacturing Engineering and Industrial Engineering.

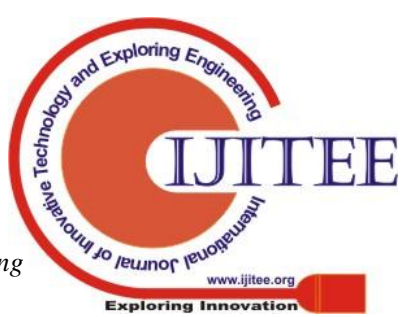

